\title{
Desarrollando cambios en nuestra lectura del mundo: Una propuesta pedagógica desde la investigación acción participativa
}

\author{
Developing Changes in Our Reading of the World: A Pedagogical Proposal from \\ Participative Action Research
}

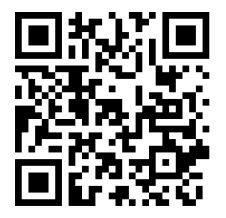

Recibido 17 de setiembre de 2016 • Corregido 23 de enero de 2017• Aceptado 11 de abril de 2017

\author{
Simona Trovato-Apollaro' \\ Universidad Nacional \\ Heredia, Costa Rica \\ simonata18@gmail.com \\ http://orcid.org/0000-0001-6195-1756
}

\begin{abstract}
Resumen: El siguiente artículo presenta la investigación que realicé con el grupo Mujeres de Teatro de Alajuelita que trata de responder a la pregunta: ¿Cómo desarrollar cambios en nuestra lectura del mundo? El propósito de nuestro estudio se dirige al proceso de toma de conciencia de las coinvestigadoras para que, a partir de sí mismas y por medio de Mujeres de Teatro, lean, interpreten y reconstruyan su entorno para provocar transformaciones en sus vidas y su comunidad. A través de la reflexión, el proceso es investigado sobre la base de las prácticas pedagógicas del Teatro del Oprimido de Boal (1980), desarrolladas en el taller de teatro en conjunto con las Mujeres de Teatro en la biblioteca del Centro Educativo Los Pinos de Alajuelita. Los principales elementos de la metodología empleada responden a la investigación acción participativa (IAP), donde la relación dialéctica participativa y la discusión colectiva posibilitan la creación de aprendizajes. Utilizamos grabaciones como instrumento para la recolección de la información que luego se sistematizan para su análisis. La posición paradigmática asumida se inspira en un enfoque relacionado con el concepto de complejidad, el cual propone una visión holística de la realidad, de la vida y, por ende, de la pedagogía, por tanto, todas las personas somos una y la multiplicidad está interconectada con cada una de las partes en continua entropía. Desde este enfoque, donde el mundo es un "sistema de sistemas" interconectados entre sí, el hallazgo principal es percibir la pedagogía como un instrumento humanizante, un objeto mágico capaz de hacernos valorar la diversidad, transformar nuestros pensamientos, estilos de vida, valores $y$, por ende, nuestra lectura del mundo. Consideramos que este importante hallazgo puede llevar a desarrollar cambios en los seres humanos y, en conclusión, inspirar una perspectiva ecológica de las relaciones, la cual podría dar origen a transformaciones profundas en nuestras estructuras sociales, políticas y económicas.
\end{abstract}

\footnotetext{
${ }^{1}$ Narradora oral, pedagoga y emprendedora cultural. Es Máster en Pedagogía con énfasis en diversidad de los procesos educativos de la Universidad Nacional, UNA (Costa Rica, 2013-15), Máster en Promoción de lectura y literatura infantil de la Universidad de Castilla-La Mancha, (España, 2009-11), Diplomada en Dirección Teatral de la Universidad de Cultura y Artes (Moscú, Rusia 1992-96). Desde 1999 se forma en Costa Rica como narradora oral y animadora de lectura con su personaje Pancita Cuentacuentos. Su trabajo es una mezcla de experiencias multiculturales que ha adquirido en Italia (su país de origen), Rusia, España y Costa Rica (donde reside actualmente). Su metodología es intermultidisciplinaria y abarca desde la utilización de las artes escénicas hasta la tecnología para la trasmisión de contenidos. Actualmente es profesora en la Universidad Nacional, Costa Rica y dirige la empresa Servicios Culturales Imaginarte, especializada en la creación y producción de proyectos culturales y educativos.
} 
doi: http://dx.doi.org/10.15359/ree.21-2.3

URL: http://www.una.ac.cr/educare

CORREO: educare@una.cr

Palabras claves: Pedagogía; diversidad; mujeres; violencia de género; complejidad; teatro del oprimido; lectura del mundo; transformación; investigación acción participativa.

\begin{abstract}
This paper presents the results of a research conducted with the group Women of Theater from Alajuelita. The research intended to answer the question of how to develop changes in our reading of the world. The goal of our study was the co-researchers' raising awareness process leading them, from themselves, and by means of the abovementioned group, to read, interpret and reconstruct the environment in order to yield transformations in their lives and community. Through reflection, the process was investigated on the basis of the pedagogical practices of Augusto Boal's Theater of Oppressed (Boal, 1980), as they were applied at the theater workshop together with the group of Women of Theather, at the library of the Educative Center Los Pinos in Alajuelita. The main elements of the implemented methodology respond to the Participative Action Research (PAR), where the dialectical participative relationship and the collective discussion make it possible the creation of learning. We used audio recordings as data collection tools, which were later systematized for their analysis. The paradigmatic position assumed was inspired by an approach related to the concept of complexity. This concept proposes a holistic view of reality, life, and, so, of pedagogy. According to such a view, we all are one, and the multiplicity is interconnected with each one of its parts, in continuous entropy. Under this approach, where the world is a system of systems interconnected among themselves, the main finding was to perceive pedagogy as an instrument for humanization, a magical object capable of valuing diversity and transforming our thoughts, life styles and values, and, in consequence, our reading of the world. We considered that such an important finding might help to develop changes in human beings and might inspire us to assume an ecological perspective towards relationships. Such a perspective might give rise to deep transformations in our social, political and economic structures.
\end{abstract}

Keywords: Pedagogy; diversity; women; gender violence; complexity; Theater of the Oppressed; reading of the world; transformation; participative action research.

\title{
Introducción
}

"Pero los libros, si bien necesarios, no hablan solos..."

Raymond Klibansnky

Mediante la escucha de la pieza "Nuvole bianche"(traducción propia del italiano: Nubes blancas) del álbum² con el mismo nombre del compositor contemporáneo Einaudi (2004), invitamos al lector o lectora a acompañarnos en nuestra IAP, que se dirige hacia la modificación de estructuras mentales (entendidas como arquetipos cerebrales que operan a la base de formas de pensar), a procesos de alfabetización y toma de conciencia que se dan mediante la práctica de una pedagogía humanizante. La propuesta desarrollada en conjunto con el grupo Las

\footnotetext{
${ }^{2}$ Se puede escuchar la pieza "Nuvole bianche" en https://www.youtube.com/watch?v=3018G1ljkCI
} 
Mujeres de Teatro de Alajuelita promueve el uso de estrategias lúdico-creativas que permiten, entre otros, la lectura, la interpretación y la reconstrucción de nuestro entorno, el pensarse y el mundo. Estas estrategias, propias del teatro del oprimido (en adelante TO), están relacionadas con la lectura del mundo, aumentan nuestras capacidades comunicativas de diálogo, para la realización de cambios a nivel comunitario. Según Freire (2004):

La lectura del mundo precede a la lectura de la palabra, de ahí que la posterior lectura de ésta no pueda prescindir de la continuidad de la lectura de aquél [del mundo]. Lenguaje y realidad se vinculan dinámicamente. La comprensión del texto a ser alcanzada por su lectura crítica implica la percepción de relaciones entre el texto y el contexto. (p. 94)

Es decir, el proceso de alfabetización no puede obviar el desarrollo de las habilidades de la lectura del mundo, no solo para ser personas que se comunican mejor con su entorno sino también para ser personas que leen y respetan la humanidad en su diversidad. Leer y pronunciar el mundo, no solo son actividades importantes, vienen a ser procesos esenciales para que siga la vida en nuestro planeta y podamos evolucionar en paz con todas las demás especies. Estos valiosos procesos permiten construir, de-construir y sentir el mundo con todas las interpretaciones existentes desde la diversidad.

Con los propósitos de las coinvestigadoras, no solo de leery pronunciar el mundo que las rodea, sino también de reconstruir su entorno y provocar transformaciones en sus vidas y comunidad, se presenta este artículo que conecta las realidades de violencia vividas por las coinvestigadoras, con contextos similares presentes en la región centroamericana y en otros continentes del mundo. La estructura de este escrito, por lo tanto, prevé: la descripción y análisis de las problemáticas elegidas a investigar en conjunto con las Mujeres de Teatro de Alajuelita; el sustento teórico sobre las categorías que se identifican en la investigación; los fundamentos pedagógico, los propósitos y las estrategias de mediación vivenciadas en los encuentros teatrales. Al finalizar este escrito se presenta una reflexión sobre los aprendizajes, hallazgos y transformaciones de las coinvestigadoras participantes, además de los posibles devenires de esta investigación.

\section{Antecedentes}

La idea de realizar esta IAP nace de mi encuentro con Alessandra Hall y Vivian Marín respectivamente la socióloga y bibliotecóloga del Centro Educativo Los Pinos de Alajuelita. Nuestro encuentro se genera en el curso de formación "Ser natural: Dramatizaciones escolares y lecturas animadas sobre culturas, ambientes y paisajes" que realicé en marzo del 2014 en la Biblioteca Pública

${ }^{3}$ Si bien la ética del escrito recomienda el anonimato de las coinvestigadoras participantes de esta IAP, las mismas han expresado el deseo de aparecer ante el público lector autorizando a que sus nombres, apellidos e imagen sean mencionados en este artículo. 
doi: http://dx.doi.org/10.15359/ree.21-2.3

URL: http://www.una.ac.cr/educare

CORREO: educare@una.cr

de Hatillo. Alessandra y Vivian venían trabajando meses atrás con un pequeño grupo de madres y vecinas cuidadoras del Centro Educativo Los Pinos en un trabajo de ayuda comunitaria, realizado gracias al aporte económico del Instituto Mixto de Ayuda Social de Costa Rica (IMAS).

La propuesta de partida era recrear el curso que se había realizado en la Biblioteca Pública de Hatillo 4 en marzo del 2014 con el estudiantado del grupo de teatro del Centro Educativo Los Pinos, pero además se quería incluir a las madres y vecinas que eran parte del grupo de apoyo del IMAS.

Analizando con Alessandra y Vivan esta primera idea, decidimos trabajar con un solo grupo específico de actores: las madres y vecinas. El fin era contracambiar el trabajo realizado, en el centro educativo con ellas, en un taller de teatro que propusiera parte de las dinámicas realizadas en el curso de Hatillo.

El curso de formación de Hatillo tenía como propósito que personal docente y de bibliotecología participante tuviera una metodología teatral para abarcar el tema de la diversidad en la clase o biblioteca. El proceso de valoración de la diversidad fue dado comenzando por reconocer la propia, además de identificar minorías o grupos discriminados en la comunidad (barrio, escuela o biblioteca).

Durante los encuentros (cinco de cinco horas en total) se realizaron lecturas y escrituras que permitieron profundizar los conocimientos de las personas participantes sobre temáticas relacionadas con la diversidad, además de montar dramatizaciones escolares con contenido de soluciones de conflictos y representaciones de roles teatrales positivos que permitían al público invitado a los festivales finales tener una nueva visión de las temáticas incursadas en el taller: identidad de género, multiculturalidad- interculturalidad, diversidad y medio ambiente. Las imágenes teatrales que nacieron del curso presentaron las siguientes temáticas: familias diversas, drogadicción, discriminación, multiculturalidad y discapacidad. Para la preparación de los talleres con las Mujeres de Teatro de Alajuelita se utilizaron algunas lecturas sobre igualdad, equidad de género y racismo presentadas en el curso de Hatillo, sin embargo, algunas de ellas fueron introducidas mediante narraciones orales o adaptadas para su mayor comprensión. Del curso de Hatillo se reutilizaron algunas técnicas del TO, así como los ejercicios escritos de "dándole vuelta" que fueron presentados mediante el árbol del dándole vuelta y la nube de devenires que se mencionan en este artículo. Se puede apreciar el resultado del curso de Hatillo viendo el video Ser Natural Costa Rica presente en You Tube (Trovato, Hernández y Acuña, 2014).

\footnotetext{
${ }^{4}$ En el 2014, gracias a un financiamiento de Proartes (MCJ) ganado por la coinvestigadora Simona Trovato, se realiza en la Biblioteca Pública de Hatillo un curso de fomento de "lectura del mundo". Dirigido a personal docente y de bibliotecología, el curso preveía la realización de un festival final comunitario dirigido a estudiantes de secundaria de escuelas públicas costarricenses. Alessandra Hall y Vivian Marín, respectivamente la psicóloga y la bibliotecóloga de la Escuela Los Pinos de Alajuelita, participaron del curso convocadas por el Ministerio de Educación Pública de Costa Rica.
} 


\section{Ruta metodológica}

Invitamos el público lector a acompañarnos en la ruta metodológica de nuestra IAP mediante la escucha de la pieza "I giorni" (traducción propia del italiano: los días), del álbum ${ }^{5}$ con el mismo nombre de Einaudi (2001). Entre julio y agosto del 2014 realizamos un proceso de diagnóstico con las coinvestigadoras Alessandra Hall y Vivian Marín y, seguidamente, con el grupo de mujeres y vecinas cuidadoras del Centro Educativo Los Pinos de Alajuelita: Lidiette Amador, Dyanna Céspedez, Ninú Obando, Ivonne Arias, María Julia Cordero. En esta fase acordamos investigar la situación vivida por las mujeres de la zona de Alajuelita en relación con la violencia doméstica y comunitaria.

Al mismo tiempo, recolectamos material literario e información a través de entrevistas semiestructuradas dirigidas al grupo de coinvestigadoras y participantes. Por otro lado, identificamos organizaciones y movimientos existentes en gestión de prevención de violencia, como la Red de Prevención de Violencia de Alajuelita, y conjuntamente dimos seguimiento a medios de información digitales. Los motores de búsqueda son páginas virtuales como el sitio de la Unicef (Fondo de las Naciones Unidas para la Infancia); el sitio oficial del Poder Judicial de Costa Rica; el sitio del Instituto Nacional de la Mujer (Inamu) y diversos medios de comunicación como La Nación Digital o crhoy.com.

De esta forma efectuamos una sistematización del diagnóstico.

Durante el mes de septiembre del 2104 me reuní con las coinvestigadoras Alessandra y Vivian para rescatar los ejercicios, las lecturas y las dinámicas realizadas en el curso de Hatillo y, así, adaptarlos a la temática de interés elegida por las participantes. A continuación, se elaboran propuestas de unidades didácticas para los diez encuentros del taller de teatro, los cuales toman vida a partir del 6 de octubre hasta el 20 de noviembre del 2014 en la biblioteca escolar del Centro Educativo Los Pinos. El día 25 de noviembre del 2014, día mundial de la no violencia, realizamos la presentación final del taller de teatro en el salón comunal de Tejarcillo en Alajuelita.

\section{Sustento teórico}

El sustento teórico abarca el estudio de categorías analizadas desde la perspectiva de las pedagogías "crítica" y de la "liberación", propias del teatro del oprimido inspiradas en la pedagogía de Paulo Freire.

Entre las categorías observadas para la investigación se destacan tres fundamentales: la diversidad, la lectura del mundo y el ambiente pedagógico.

\footnotetext{
${ }^{5}$ Se puede escuchar "I giorni" en https://www.youtube.com/watch?v=r0gzCptvSSA
} 
doi: http://dx.doi.org/10.15359/ree.21-2.3

URL: http://www.una.ac.cr/educare

CORREO: educare@una.cr

\section{Sobre la diversidad}

Según Link y Phelan (2001), el estigma existe cuando convergen los siguientes componentes interrelacionados:las personas distinguen yetiquetan las diferencias humanas; las creenciasculturales dominantes vinculan a las personas que ya fueron etiquetadas con características indeseables; las personas etiquetadas son colocadas en distintas categorías con el fin de crear una separación entre "ellas" y"nosotras"; las personas etiquetadas experimentan una pérdida de estatus y discriminación que conducen a resultados desiguales. Para ello, la teoría Queer (Fonseca y Quintero, 2009) realiza un estudio político de dichas etiquetas con el fin de dignificar y hacer visible los colectivos de mujeres, de personas negras, indígenas, panteístas, transexuales, pobres, entre otros. En esta investigación proponemos que todas nosotras expresemos la visión social estigmatizada que vivimos para poder liberarnos de los prejuicios internos que cada una puede tener frente a la diversidad.

Según la lectura de la propuesta Queer realizada por Fonseca y Quintero (2009), la cual es apoyada por las coinvestigadoras de esta IAP, la filósofa Judith Butler considera que el género no existe, es una construcción social de plena imitación y teatralidad; además, mencionan que, para Rafael Mérida, dicha corriente Queer rechaza toda clasificación que destruye toda identidad sexual (gay, lésbica, trans, travesti, heterosexual) y la engloba en un mundo subversivo y transgresor que promueve un cambio social colectivo contra la homofobia, el racismo, la misoginia, y otras forma de opresión.

Todo lo anterior se relaciona con esta posibilidad de desestabilizar normas aparentemente fijas que se vinculan con la deconstrucción del poder, del cual dependen los estigmas, su reproducción y permanencia. De esta forma, los autores concuerdan con que el estigma depende del poder, y se manifiesta en los roles de género.

En el mismo sentido, Regina (2013), por medio de un lenguaje directo y liberatorio, recuerda que los abusos sufridos a diario por cualquier mujer de cualquier parte del mundo no son más que la expresión de una cultura machista hegemónica imperante desde hace cinco mil años, la cual sigue manteniendo su estatus represor hacia el género femenino (y otros grupos discriminados) limitando su acceso a la educación, al trabajo y a la política.

Traemos a colación la temática de la construcción patriarcal en el marco de la violencia de género que ha sido naturalizada e institucionalizada, no solo por los hombres, sino también por las mujeres (Obando, 2011). Según Lagarde (2012), el sexismo es un ejemplo de ello y uno de los pilares de nuestra cultura patriarcal (otros pilares son el machismo y la homofobia) y de nuestras mentalidades. Como propone Lagarde (2012): "somos sexistas cada vez que justificamos su dominio [de los hombres o cualquier ser humano] y les tememos como si fuesen seres extraordinarios o sobrenaturales, y cuando nos derrotamos y desvalorizamos frente a ellos" (p. 23). Lagarde recuerda que el autoetiquetarse y subordinarse ante otros seres humanos refleja cómo las mujeres actúan con sexismo, y da una alerta, diciendo que: 
El sexismo es parte del patriarcalismo de nuestro mundo: inunda las filosofías las teorías científicas y las doctrinas religiosas más apreciadas y el sentido común, se difunde a través de las instituciones y los medios de comunicación, goza de consensos en grados diversos y permea la mayor parte de la vida cotidiana y de nuestras biografías. Se transmite y ejerce cuerpo a cuerpo, persona a persona. ... El sexismo es contenido fundamental de la autoidentidad. Por eso las personas lo aprenden, lo internalizan lo adecuan y recrean: lo convierten en afectos, pensamientos, prejuicios y veredictos, en moral y norma de conducta, y en cristal para ver al mundo y a sus habitantes. El sexismo es pilar de la inquisición que cada quien lleva dentro. (p. 25)

El fenómeno de los privilegios masculinos se encuentra también en el estatus socialmente creado sobre el hombre blanco, esta idea de Mcintosh (1989) se relaciona con que existen privilegios invisibles que, por educación, los mismos sujetos privilegiados no acostumbran identificar.

Para Obando (2011), el paradigma patriarcal va más allá de la simple discriminación por género, de forma que esta es una manifestación articulatoria que interactúa con otros sistemas de opresión o privilegio, tal como es la etnia, la nacionalidad, el estatus migratorio, la edad, la religión, la clase, entre otros. Así es como la naturalización de la lógica patriarcal, de dichas estructuras de poder, permite un espacio idóneo para la dominación de un género sobre el otro.

Deducimos, entonces, que en la base de la no violencia está la igualdad de oportunidades, la aceptación de la otredad, de la diversidad, sea la que sea, incluyendo la de todo ser humano. Identificamos así la diversidad y la igualdad de género como los pilares de nuevas prácticas reales de vida que Lagarde (2012) identifica como democracias genéricas, las cuales no están basadas en el poder y el dominio de ningún género sobre otro, sino en formas de convivencia y entendimiento basadas en los derechos humanos de género, los cuales incluyen los derechos de las humanas. Según Lagarde (2012), una nueva cultura de género se basa en:

La solidaridad entre mujeres y hombres precisa el reconocimiento de la humanidad del otro, de la otra, y la posibilidad de identificar las semejanzas y las diferencias como tales y no como desigualdades. Esta solidaridad inter genérica se basa en la defensa de la libertad y del poderío personales y colectivos para ambos géneros, así como la posibilidad de establecer pactos justos y paritarios entre mujeres y hombres. La solidaridad genérica surge de la empatía entre iguales y distintos que suman esfuerzos vitales de diversa índole para actuar en el mundo. (pp. 33-34)

Importante tema propuesto por Freire (2002) es el de la multiculturalidad que consiste en que cada individuo tiene derecho a ser diferente, sin miedo a ser diferente, a poder moverse. Habla también de la necesaria unidad en la diversidad, de no creerse minorías aisladas sino darse cuenta de que solo hay una minoría que oprime, y también de que el cambio no es espontáneo, sino que se construye. 
doi: http://dx.doi.org/10.15359/ree.21-2.3

URL: http://www.una.ac.cr/educare

CORREO: educare@una.cr

Al respecto Boal (2004), en Arco iris del deseo. Del teatro experimental a la terapia, propone un teatro al servicio de la liberación personal en la búsqueda de hacer valer nuestros derechos. Dicha liberación personal es abarcada desde la propuesta de Freire (2002), que ve la educación como un acto político donde pensar y actuar está conectado, en conjunto, con nuestros sueños, utopías y esperanzas.

\section{Sobre la lectura del mundo}

Según Freire (2004):

Saber leer y escribir es relativamente fácil, pero tener la capacidad para desarrollar un constante proceso cognoscitivo [que pronuncie] el mundo, requiere un esfuerzo mayor, para esto es necesario que los hombres y las mujeres asuman un papel creativo y pensante ante su realidad. (p. 17)

En este sentido, la capacidad de leer el mundo viene a finalizar un proceso de alfabetización que permite al ser humano pronunciar el mundo (la lectura de la realidad), crear y recrear su historia.

Para el pedagogo brasileño, en la sociedad actual donde vivimos hay una tendencia a separar texto y contexto: el texto se desarrolla como un proceso metafísico, como un discurso abstracto sin vinculación con la realidad. Para Freire (2004):

El auténtico acto de leer es un proceso dialéctico que sintetiza la relación existente entre conocimiento-transformación del mundo y conocimiento-transformación de nosotros mismos. Leer es pronunciar el mundo, es el acto que permite al hombre y a la mujer tomar distancia de su práctica (codificarla) para conocerla críticamente, volviendo a ella para transformarla y transformarse a sí mismos. (p. 17)

Freire propone importantes preguntas: ¿Qué significado adquiere leer el mundo en nuestro tiempo? ¿Cómo y para quién se debe leer el mundo? Y recuerda que esta categoría tiene como finalidad el análisis de lo que significa leer el mundo, permitiendo la vinculación entre lo que se lee y la realidad, sin lo cual no sería posible llevar a cabo un verdadero proceso de conocimiento transformador del ser humano en su entorno.

Traemos a colación el tema del imaginario social, el cual está en la base de la vinculación entre lo que se lee y la realidad. El imaginario social es un concepto creado por el filósofo griego Castoriadis (1993), usado habitualmente en ciencias sociales para designar las representaciones sociales encarnadas en sus instituciones. Según el autor griego Castoriadis, el término "imaginario social" representa la concepción de figuras/formas/imágenes de aquello que los 
sujetos Ilamamos "realidad". El concepto se usa habitualmente como sinónimo de mentalidad, estructura mental, cosmovisión, conciencia colectiva o ideología, sentido común o racionalidad en una sociedad. Según Taylor (2006), es:

El modo en que [las personas] imaginan su existencia social, el tipo de relaciones que mantienen con otras, el tipo de cosas que ocurren entre ellas, las expectativas que se cumplen habitualmente y las imágenes e ideas normativas más profundas que subyacen a estas expectativas. (p. 38)

El imaginario social difiere de una teoría social en cuanto no se expresa en términos teóricos (sin bien estos pueden influir en él), sino a través de imágenes, historias y leyendas. Además, compartido por amplios grupos de personas, hace posible las prácticas comunes y un sentimiento ampliamente compartido de legitimidad.

Nuestro imaginario social es complejo y depende de la participación de cada quien en la práctica común, en un tiempo, en el espacio (físico y social) y en las circunstancias históricas vividas. Detrás de la construcción del imaginario social existe una idea de orden moral o metafísico, donde cobran sentido las normas y los ideales sobre los cuales se construyen las relaciones que mantenemos entre nosotros y nosotras o con el poder.

La característica fundamental del imaginario social, que tiene en común con la materia y el ser, es que está sujeto a cambios o a transformaciones provocadas por nuevas prácticas, improvisaciones o teorías sociales.

En esta investigación se tiene la oportunidad de obrar sobre nuestro imaginario social, mediante la técnica del teatro imagen que proporciona el teatro del oprimido de Boal (1980).

\section{Sobre el ambiente pedagógico}

Según Matos (2011), imaginario social y teatro contienen en su raíz elementos comunes. Si bien el imaginario social es una estructura poco estudiada desde su vínculo con la cultura comunitaria, este actúa como sistema y no nos percatamos de su presencia en el campo de las ideas, en la creación, en las significaciones o, en general, en el mundo del ser humano expresado en lo simbólico.

El teatro está en la base de esta IAP como instrumento de mediación pedagógica en cuanto permite obrar sobre el imaginario social de los seres humanos. Imaginario social y teatro son creadores de memorias y de identidades entre los miembros de comunidades, en la interacción de unas personas con las otras y en la actuación de los seres humanos sobre las cosas, sobre el significado que dichas cosas tienen para sí. El trabajo de la actuación es identificar y priorizar qué hechos actuar (vicios, costumbres, derechos, motivación). De allí la enorme importancia 
doi: http://dx.doi.org/10.15359/ree.21-2.3

URL: http://www.una.ac.cr/educare

CORREO: educare@una.cr

asignada a quien actúa para interpretar el mundo social, analizarlo, provocar la acción social y actuar en el interaccionismo simbólico. Por lo tanto, el teatro en la perspectiva de Matos, solo puede ser el espacio donde aprenden unos individuos de los otros, en la perspectiva de una transformación social, de un cambio para una situación o un contexto comunitario.

El teatro, como otras artes, lleva en sí el imaginario social de una cultura. Su comprensión debe ser entendida como interacción de los individuos en los procesos de formación de conductas, valores, apreciaciones, gustos e ideales, los cuales están sujetos a las prácticas sociales y discursivas de nuestro tiempo. Según Boal (2004, p. 25):

El teatro es la primera invención humana, la que permite y promueve todos los demás inventos. El teatro nace cuando el ser humano descubre que puede observarse a sí mismo $y$, a partir de ese descubrimiento, empieza a inventar otras maneras de obrar.

El teatro da la posibilidad de ver desde diferentes puntos de vista una situación. Dicha coyuntura da la oportunidad de crecer como personas, hace posible que ellas se entiendan entre sí o lo que están viviendo internamente y sus circunstancias. Este proceso, pedagógico, narrativo y teatral da también la posibilidad de tomar conciencia, ofrece herramientas para la modificación de conductas y da la posibilidad a la sociedad de tener algo en qué pensar para tener mejores personas cada día. En concordancia con esto, Freire (2004) señala:

La conciencia no se transforma más que en la praxis... Solamente ... en la unidad de la práctica y la teoría, de la acción y la reflexión, es posible superar el carácter alienante de la cotidianidad, como expresión de nuestra manera ... de movernos en el mundo o como resultado de una acción que se mecaniza o se burocratiza. (pp. 32-33)

Adicionalmente, para la construcción del ambiente pedagógico del taller de teatro que está en la base de nuestra investigación, se rescatan los valores del cuido y del amor.

Para Maturana (2002), estamos necesitados más que nunca de una cultura educativa alternativa que promueva relaciones basadas en el amor, en relaciones sociales que constituyen aperturas para compartir y colaborar por el placer de hacerlo, y sin ninguna expectativa de retribución.

En el mismo sentido, percibimos la necesidad de crear una nueva cultura basada en el cuidado mutuo que, también, se ha de reflejar en la escuela del cuidado, donde sea central el desarrollo y la promoción de seres humanos sujetos de su propia vida y de su propia historia. Personas que se construyen, en una relación de autocreación y autoorganización (autopoiesis de Assmann), como sujetos en procesos autónomos, cooperadores, justos, equitativos, libres, críticos, compasivos y fraternos. A confirmación de esto, Dolz y Rogero (2012) sugieren:

\begin{tabular}{l|l}
\hline 10 & Simona Trovato-Apollaro
\end{tabular}

Los artículos de la Revista Electrónica Educare del Centro de Investigación y Docencia en Educación de la Universidad Nacional, Costa Rica, se comparten bajo términos de la Licencia Creative Commons: Reconocimiento, No Comercial, Sin Obra Derivada 3.0 Costa Rica. Las autorizaciones adicionales a las aquí delimitadas se pueden obtener en el correo: educare@una.cr 
La construcción de un nuevo modelo de sociedad requiere desmercantilizar las relaciones sociales para hacerlas relaciones sociales basadas en el amor y el cuidado mutuo. Para ello, no hay otro camino que la promoción del cuidado mutuo en todo lugar y en todo momento, como un rasgo fundamental de la especie humana. (p. 104)

Así mismo Maturana (2002, citado en Dolz y Rogero, 2012) afirma que"nosotros los seres humanos, pertenecemos a una historia evolutiva definida por un modo de vida centrado en el amor, no en la agresión, de tal modo que enfermamos a cualquier edad cuando se nos priva de amor" (p. 104).

\section{Contexto histórico actual}

En cuanto a las condiciones del contexto histórico, a grandes rasgos podemos señalar que Costa Rica se encuentra en una fase de transformación y acomodo, debido al cambio de gobierno (2014) que ha sido importante tras décadas de bipartidismo. Además, vemos cómo económicamente se sufren los efectos de la crisis financiera e ideología política neoliberal generada en Estados Unidos y Europa (primeros socios comerciales de Costa Rica), locual repercute directamente sobre la economía del país. Adicionalmente, se percibe una sociedad aún muy normativista, heteropatriarcal, verticalista, sexista y homofóbica, fundada en el individualismo y en un imaginario social referente a creencias religiosas monoteístas y patriarcales.

Por otro lado, en el contexto de la seguridad ciudadana, Costa Rica presenta una tendencia ascendente en femicidios, así como en delitos asociados al tráfico de drogas, robos o asaltos, lo cual ha contribuido notablemente a una creciente percepción de inseguridad ciudadana.

En lo que concierne a Alajuelita, Desamparados, Hatillo y Coronado, nos encontramos frente a un momento de pico de violencia urbana generada principalmente por el tráfico de drogas y luchas entre bandas en pugna por dominar la venta de sustancias ilegales. Dicha violencia urbana no afecta solamente a los integrantes de las bandas o "pandillas", sino también a la ciudadanía que se encuentra en los sitios donde se genera la violencia. Según el artículo de Murillo (2014), actualmente la suma de armas de fuego legalmente registrada es de 230.000 y se calcula otro tanto para las ilegales, por un aproximado de un arma por cada diez costarricenses.

A pesar de que el $80 \%$ de las muertes por homicidios con armas de fuego son efectuadas por la criminalidad organizada, hay otro índice destacable de muertes violentas que son las provocadas a mujeres por arma blanca como femicidio y condición de género. De acuerdo con Salas (2012), en el estudio Mujeres, realizado por la ONU, se describe: 
doi: http://dx.doi.org/10.15359/ree.21-2.3

URL: http://www.una.ac.cr/educare

CORREO: educare@una.cr

Laviolencia contrala mujeren Latinoaméricaes responsable de más muertesy discapacidades que los efectos combinados del cáncer, la malaria, accidentes de tránsito y la guerra.

Nuestro país [Costa Rica] no es la excepción, ya que a pesar de los programas, campañas, la implementación de juzgados especializados para la mujer e instituciones que las apoyan, las tasas de femicidio y violencia contra las mujeres no muestra progreso alguno [no mejora] y, más bien, siguen en aumento.

El año anterior [durante el 2011], los femicidios cobraron la vida de 40 mujeres costarricenses. Las estadísticas señalan que 12 de ellas murieron en manos de sus esposos o de sus compañeros sentimentales -dos más que en el año 2010- y 28 más fueron asesinadas por sus ex parejas -8 más que en el 2010-. (párr. 1-3)

Si ampliamos la mirada a Centroamérica, en cuanto a los crímenes contra las mujeres, la situación empeora notablemente. Sobre este tema el artículo del periódico hondureño EI Heraldo la Redacción (2014) plantea:

Entre el 2002 y septiembre de 2014 Honduras registró 4,217 crímenes contra mujeres, ocupando en los últimos años el segundo lugar en femicidios a nivel de la región, superada nada más por Guatemala. Un estudio de la Red de Seguridad y Defensa de América Latina (Resdal) analiza este problema, así como el aumento de otra serie de delitos con que las autoridades del área deben lidiar.

En cuanto a los crímenes contra las mujeres, usando datos de 2012, el documento mostró que ese año Guatemala presentó 708 casos, Honduras 606, El Salvador 320, Nicaragua 65, Panamá 28 y Costa Rica 26 casos...

Los países del llamado Triángulo Norte (Guatemala-El Salvador-Honduras) aparecen con la mayor cantidad de violencia contra las mujeres. (párr. 1-4)

Agrandando la mirada al contexto mundial en cuanto a violencia, es imposible obviar la actual situación que están sufriendo miles de mujeres de otros continentes como la nueva ola de violaciones hacia las mujeres. Niñas, mujeres y ancianas en la India; las doscientas niñas nigerianas secuestradas por el movimiento islamista Boko Haram, y sus últimas praxis de utilización de niñas kamikaze (como menciona el artículo en italiano de Olimpio, 2015) "Innocenti e insospettabili" [Inocentes e insospechables] que han provocado atentados con centenares de muertos. Estos hechos se asocian a otros tipos de violencia que sufren las mujeres y los hombres en distintos contextos, porque la violencia genera violencia y, por lo tanto, está interconectada entre sí, como el mundo, sea la que sea. Por ejemplo, el atentado del pasado 7 de enero en París contra el semanario satírico Charlie Hebdo, donde asesinaron brutalmente a diez de sus integrantes por la provocación del mundo árabe. De la misma forma, es imposible olvidar las miles de personas que, actualmente, mueren de manera constante en el mar Mediterráneo en su intento por llegar a Europa huyendo 
de las guerras (económicas, políticas o religiosas) en sus países. Y cómo obviar las muertes de los seres humanos que anualmente realizan viajes brutales desde centro y sur América, tratando de cruzar la frontera hacia Estados Unidos en búsqueda de mejores oportunidades.

Los acontecimientos inhumanos sobrecitados indican que actualmente la libertad (de expresión también), la fraternidad y la igualdad son valores aún inalcanzables para la especie "humana" y que los principios de derechos humanos se hacen siempre más inasibles. En este mismo sentido, es evidente que la violencia y la frustración que se viven en el microcontexto, como el familiar o el comunitario de un barrio, genera nueva violencia al Estado macro. Esta imagen presenta a la violencia (social o económica) como una enorme red entrelazada, interconectada y presente en todos los continentes, en cada vivencia de los seres humanos del planeta Tierra.

Cabe resaltar que la crisis actual a nivel mundial no es una crisis de violencia y economía sin más. Es una crisis sistémica que afecta todos los aspectos del diario vivir humano. Pero, sobre todo, afecta la sensibilidad humana. Según Dolz y Rogero (2012):

En ella se ha producido una mentalidad patologizada que contempla a la naturaleza y a los demás como objetos para su disfrute. Eso está produciendo una gran deshumanización. Hoy es necesario cambiar la mentalidad del depredador por la de jardinero. La humanización de la humanidad se nos impone como una necesidad ineludible. (pp. 103-104)

A pesar de este momento histórico sumamente violento, nuestra voluntad apela a la esperanza. Por esta razón, en esta investigación, concebimos el contexto histórico como un conjunto de posibilidades que pueden hacerse y rehacerse según las voluntades y la praxis.

De esta forma, tenemos muy presente la importancia de la acción ligada a la reflexión y a la praxis, tal como la identifica Freire (2004, pp. 27- 28):

La historia no hace nada, no posee ninguna riqueza, no libra ninguna clase de lucha: quien hace todo esto, quien posee y lucha es el hombre mismo, ... el real, vivo; no es la historia que utiliza al hombre para alcanzar sus fines -como si se tratase de una persona aparteporque la historia no es sino la actividad ... que persigue sus objetivos.

Asimismo, el cantautor italiano De Gregori (1985), en su canción La storia [La historia] del álbum "Scacchi e tarocchi" [Ajedrez y tarot] ${ }^{6}$, presenta la historia en diferentes modos, pero resulta evidente, en el texto, que ella está hecha sobre todo por el pueblo, por la gente común, por la gente activa que actúa y produce, y no solamente por los individuos escogidos por Dios. El verdadero protagonista de la canción es el pueblo, que actúa dentro de la historia y hace la historia.

${ }^{6}$ Se puede apreciar la canción "La Storia" en https://www.youtube.com/watch?v=xMXi9ftO4kl 
doi: http://dx.doi.org/10.15359/ree.21-2.3

URL: http://www.una.ac.cr/educare

CORREO: educare@una.cr

\section{El grupo de coinvestigadoras y sujetas participantes}

El grupo de coinvestigadoras y sujetas participantes de esta IAP lo conformamos nueve mujeres: Alessandra Hall, Vivian Marín, Simona Trovato, Lidiette Amador, Ninú Obando, Dayana Céspedez, Julia Cordero, Ivonne Arias y Yamileth Fontana. Las edades oscilan entre los veintiocho y los cincuenta y siete años de edad, dos de ellas, Ninú y Dyanna son madre e hija. Somos vecinas de la Aurora de Alajuelita, de Curridabat y de San Pedro de Montes de Oca, la mayoría provenientes del Valle Central y de Guanacaste. Mi nacionalidad es italiana y radico en Costa Rica desde hace 18 años. Nuestras profesiones son variadas y abarcan desde el ama de casa la cocinera, la narradora oral, la psicóloga, la socióloga hasta una bibliotecóloga (ver Figura 1).

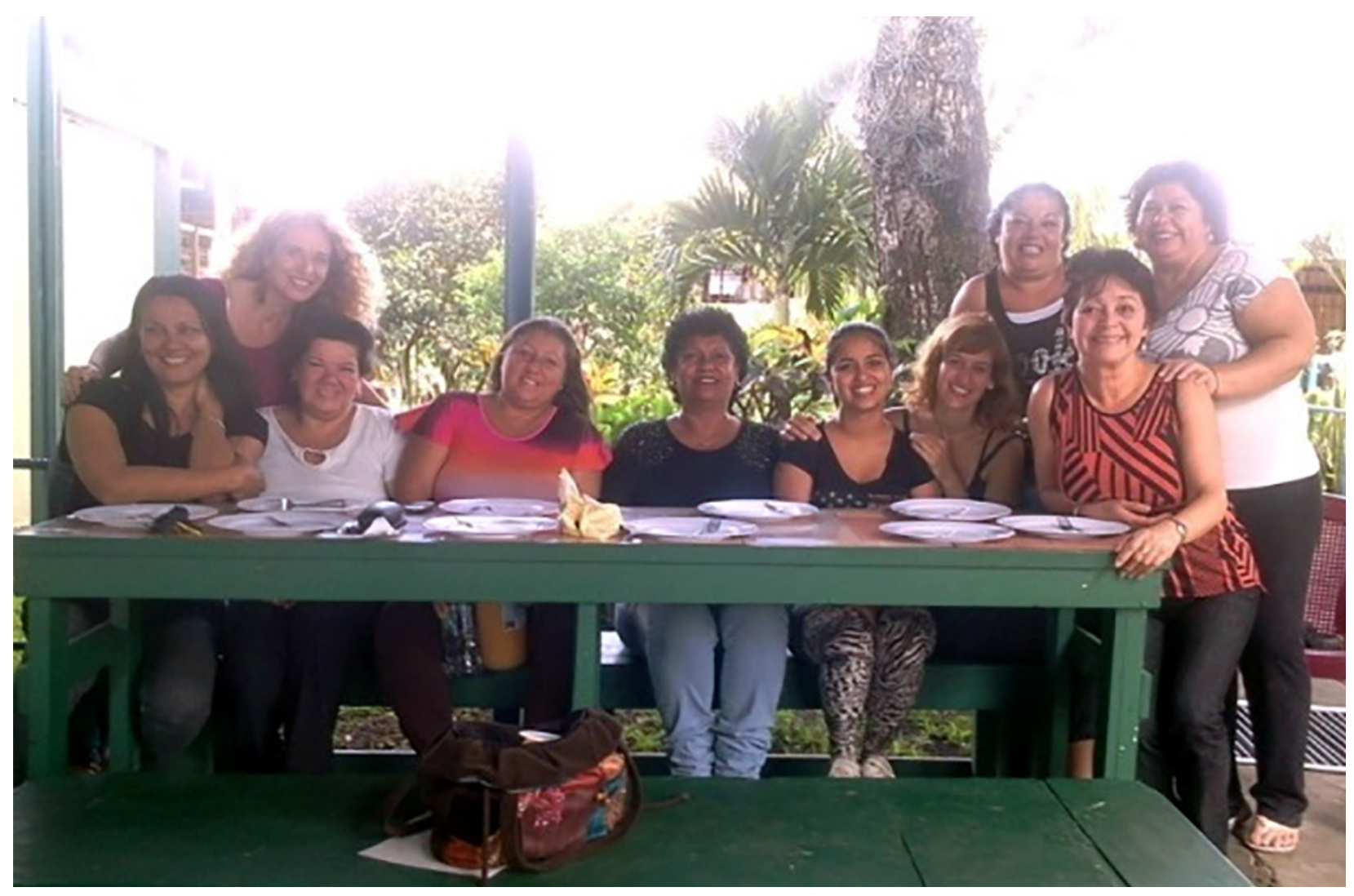

Figura 1: El grupo Mujeres de Teatro en el comedor del centro educativo Los Pinos de Alajuelita. Nota: Cada participante ha autorizado el uso de su imagen. 
Desde el primer encuentro nos percibimos más que mujeres, madres, hijas, profesionales o vecinas cuidadoras. Las nueve participantes nos percibimos a nosotras mismas como personas que quieren ser mejores cada día para crecer física y personalmente como seres humanos libres; como personas alegres y participativas; como mujeres valiosas, valientes, autónomas, libres y con muchas ganas de ser y de cambiar realidades.

Respondiendo a estos atributos, decidimos llamarnos Mujeres de Teatro y encontrarnos una vez por semana, durante diez secciones de trabajo, en la biblioteca del Centro Educativo Los Pinos de Alajuelita. Nuestro mayor deseo es reconectarnos con los sueños, las esperanzas y asumirnos como agentes de cambio en la comunidad de Alajuelita. Asimismo, determinamos que el tema de interés a investigar en el taller es la violencia intrafamiliar y comunitaria. Para lograr este fin, definimos los propósitos universales y específicos del taller de teatro que exponemos a continuación.

\section{Propósito amplio}

Provocar una transformación en la comunidad de Alajuelita mediante el uso de las herramientas de las artes escénicas, con el fin de construir conocimientos para formarse sobre temáticas relacionadas con la diversidad, y con la violencia intrafamiliar y comunitaria.

\section{Propósitos específicos}

1. Realizar ejercicios teatrales para el desarrollo de nuestra personalidad, del conocimiento de nosotras mismas, de la empatía, del sentido de grupo, de la tolerancia y respeto hacia la otredad.

2. Reconocer nuestra diversidad individual y la diversidad en general como un valor fundamental básico de los derechos humanos y del medio ambiente.

3. Identificar las relaciones de poder en el aula, en el centro educativo, en los ámbitos familiar y laboral o en la comunidad.

4. Identificar grupos con desigualdad de condición, minorías y grupos discriminados de la comunidad para su análisis y representación en las dramatizaciones escolares y valorar el rol de las personas aliadas.

5. Generar acciones para la creación de imágenes visuales antidiscriminatorias y el uso del lenguaje inclusivo por parte de la comunidad educativa.

6. Profundizar e interiorizar las temáticas propuestas en el curso por medio de lecturas, escrituras, narraciones orales, teatro imagen, teatro invisible y teatro foro. 
doi: http://dx.doi.org/10.15359/ree.21-2.3

URL: http://www.una.ac.cr/educare

CORREO: educare@una.cr

\section{Metodología}

Los diez encuentros del taller de teatro rescatan la técnica del teatro del oprimido, que se basa en la Pedagogía del oprimido del pedagogo Freire (1972), la cual está determinada por la relación dialéctica entre teoría-método y por el contexto de lucha en el que se ubica la práctica educativa específica. Siguiendo esta propuesta pedagógica, las técnicas del TO y la metodología de la IAP, el grupo de coinvestigadoras decide cuál es el tema a investigar, cómo desarrollarlo, elige qué se espera, qué falta, y plantea tanto los propósitos como los devenires del taller. Esta metodología permite construir en conjunto el conocimiento al entrelazar saberes basados en lo sugerido por Freire (1982): "Nadie educa a nadie; ... los hombres se educan entre sí, mediatizados por su mundo" (pp. 17-18).

La técnica del teatro imagen de Boal (1980) permite reconocer el poder que se genera en una situación dada, quién lo tiene, quiénes son las fuerzas opresoras y quiénes las oprimidas. Consiste en crear tres imágenes sobre una temática de atención prioritaria elegida por la misma comunidad donde se trabaja. La primera imagen es el tema del conflicto, multiplicado a la enésima potencia; la segunda es la de un evento que lleva a la resolución del conflicto; y la tercera, y última imagen, la ideal. Esta secuencia, en su construcción, no es siempre igual, lo importante es representar el conflicto que se quiere abordar para presentarlo al público.

En el teatro del oprimido de Boal (1980), la interacción con el público es constante, tanto, que quienes actúan y el público espectador son todos al mismo tiempo espectactores o espectactrices. Esto significa que el público puede intervenir en la presentación de las imágenes, leerlas, comentarlas, mejorarlas y hacer parte de ellas. Este tipo de teatro permite conectar a "espectadores y espectactrices" con su imaginario social, revivenciarlo y discutirlo para la creación de nuevos imaginarios sociales.

Con base en el análisis sobre el imaginario social realizado en los encuentros, y al tema de nuestra IAP, construimos las tres imágenes en la biblioteca escolar de la Escuela Los Pinos de Alajuelita que, finalmente, fueron presentadas el 25 de noviembre del 2014 en el Salón Comunal de Tejarcillo, Alajuelita.

La primera imagen (Figura 2) presenta el espacio de la sala de una casa, en ella están cuatro personajes: una esposa, un esposo, y las dos suegras. Afuera de este cuadro, al lado derecho del escenario, se ven otras dos mujeres, quienes tocan a la puerta de la casa.

Con esta imagen (Figura 2), queremos representar la problemática de los celos por parte de los hombres sobre "sus" mujeres, el sentido de pertenencia que tienen sobre ellas y su tiempo, incluyendo el de la diversión. Entre los dos esposos hay tensión, realmente están viviendo una discusión, y entre ellos está una de las dos suegras que trata de calmarlos. El conflicto radica en el hecho de que el hombre no quiere que la mujer salga con sus amigas. Al lado izquierdo del 
doi: http://dx.doi.org/10.15359/ree.21-2.3

URL: http://www.una.ac.cr/educare

CORREO: educare@una.cr

escenario, está la segunda suegra leyendo la Biblia, ella no participa de lo que está sucediendo porque se siente huésped en la casa del yerno.

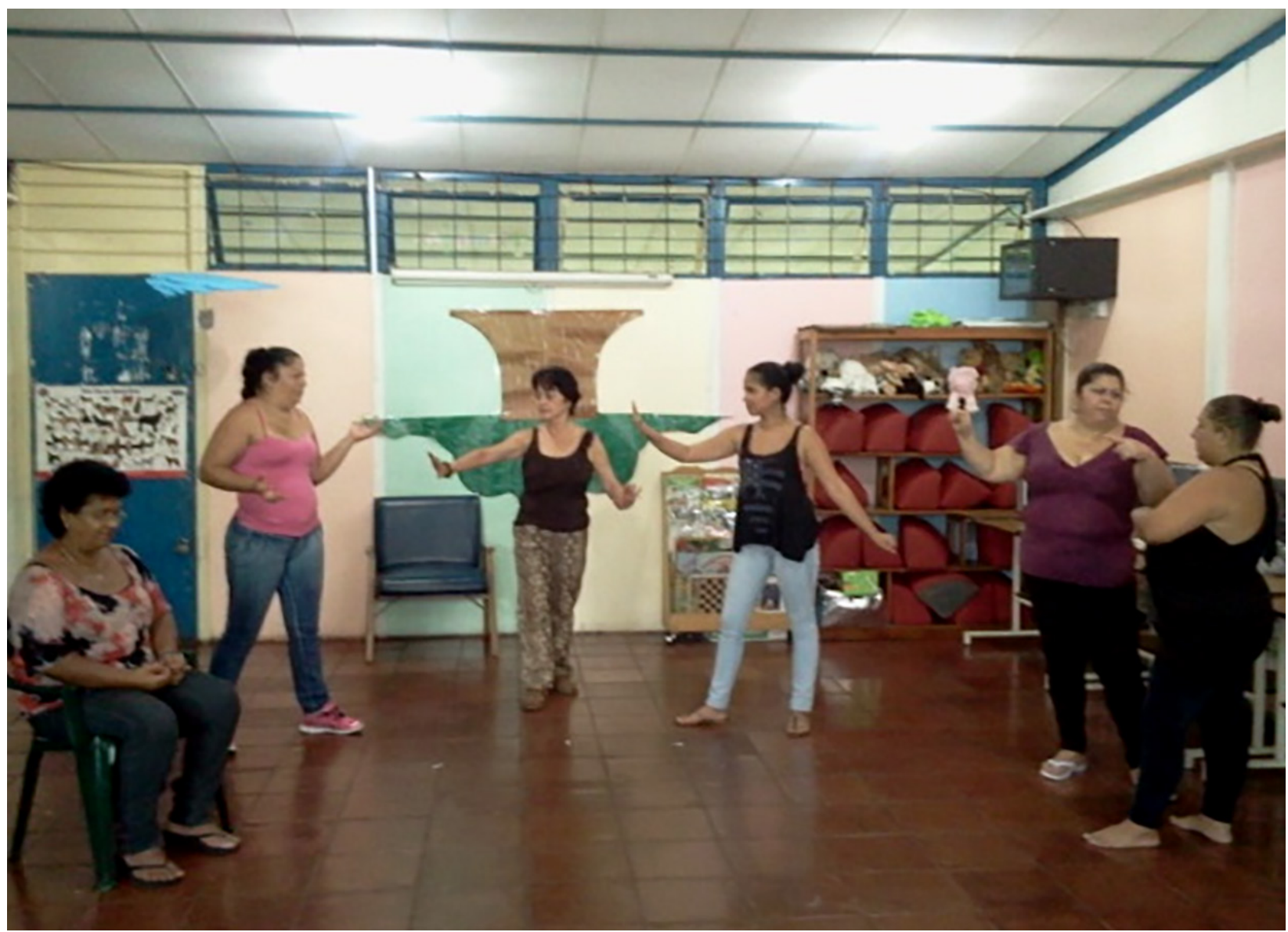

Figura 2: Situación de presentación del conflicto. Nota: Cada participante ha autorizado el uso de su imagen. Nota: Cada participante ha autorizado el uso de su imagen.

En la segunda imagen (Figura 3) vemos al esposo sentado entre las dos suegras, él está pasando por un momento de mucha vulnerabilidad y nerviosismo, las dos suegras tratan de calmarlo y le hablan. La esposa al mismo tiempo está hablando con sus amigas. Para esta escena se propone evidenciar cómo el diálogo en familia permite superar situaciones de conflicto para no llegar a la generación de violencia; además, la vecindad entre la esposa con sus amigas confirma el derecho de la mujer a salir y disponer de su tiempo como quiere. 
doi: http://dx.doi.org/10.15359/ree.21-2.3

URL: http://www.una.ac.cr/educare

CORREO: educare@una.cr

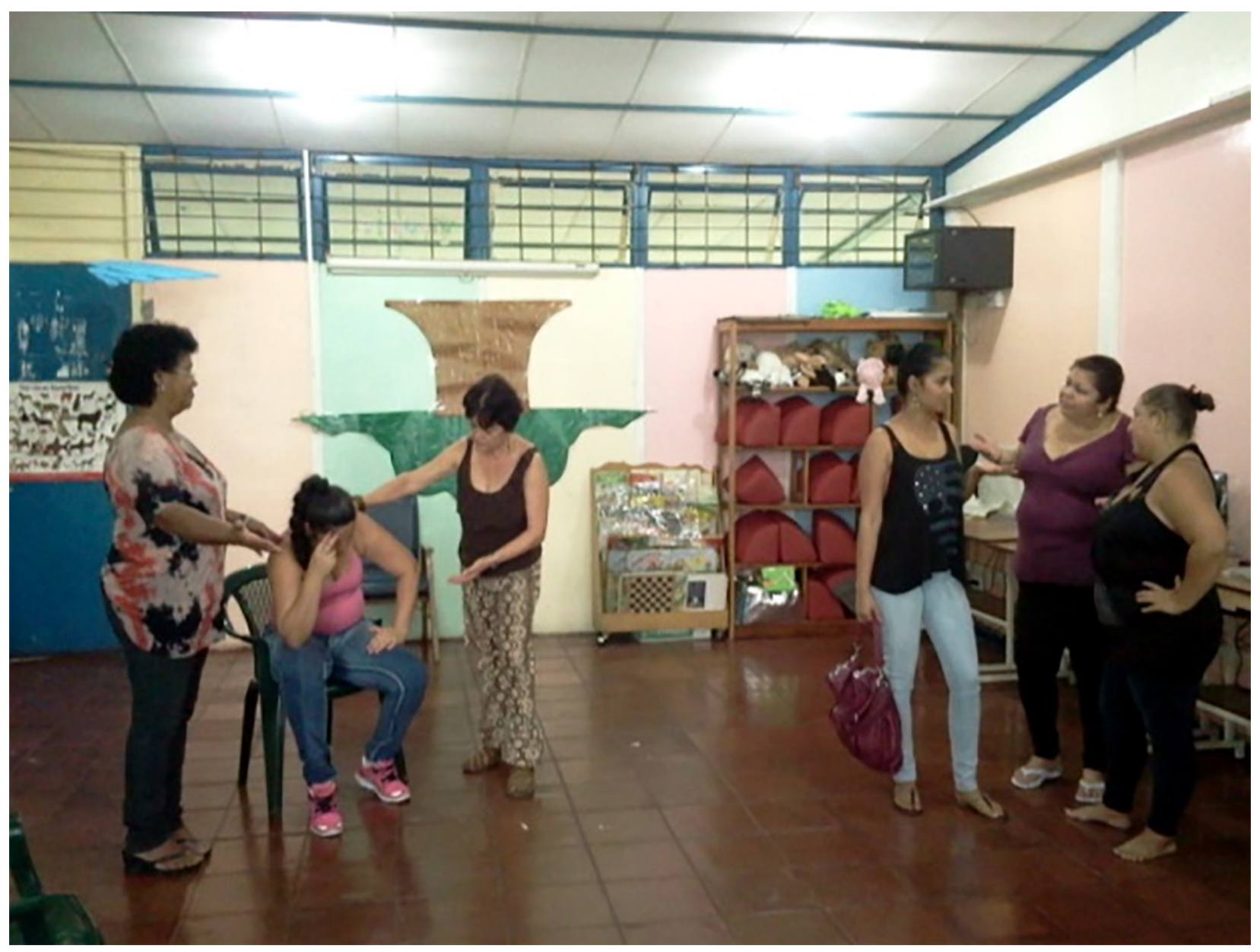

Figura 3: Situación de diálogo.

Nota: Cada participante ha autorizado el uso de su imagen.

La tercera y última escena presenta la imagen ideal (Figura 4): el marido ha tomado conciencia, gracias al dialogo que ha tenido con la suegra y su madre, él les sirve café y la esposa se despide con un beso en la mejilla para salir con sus amigas que la esperan. 


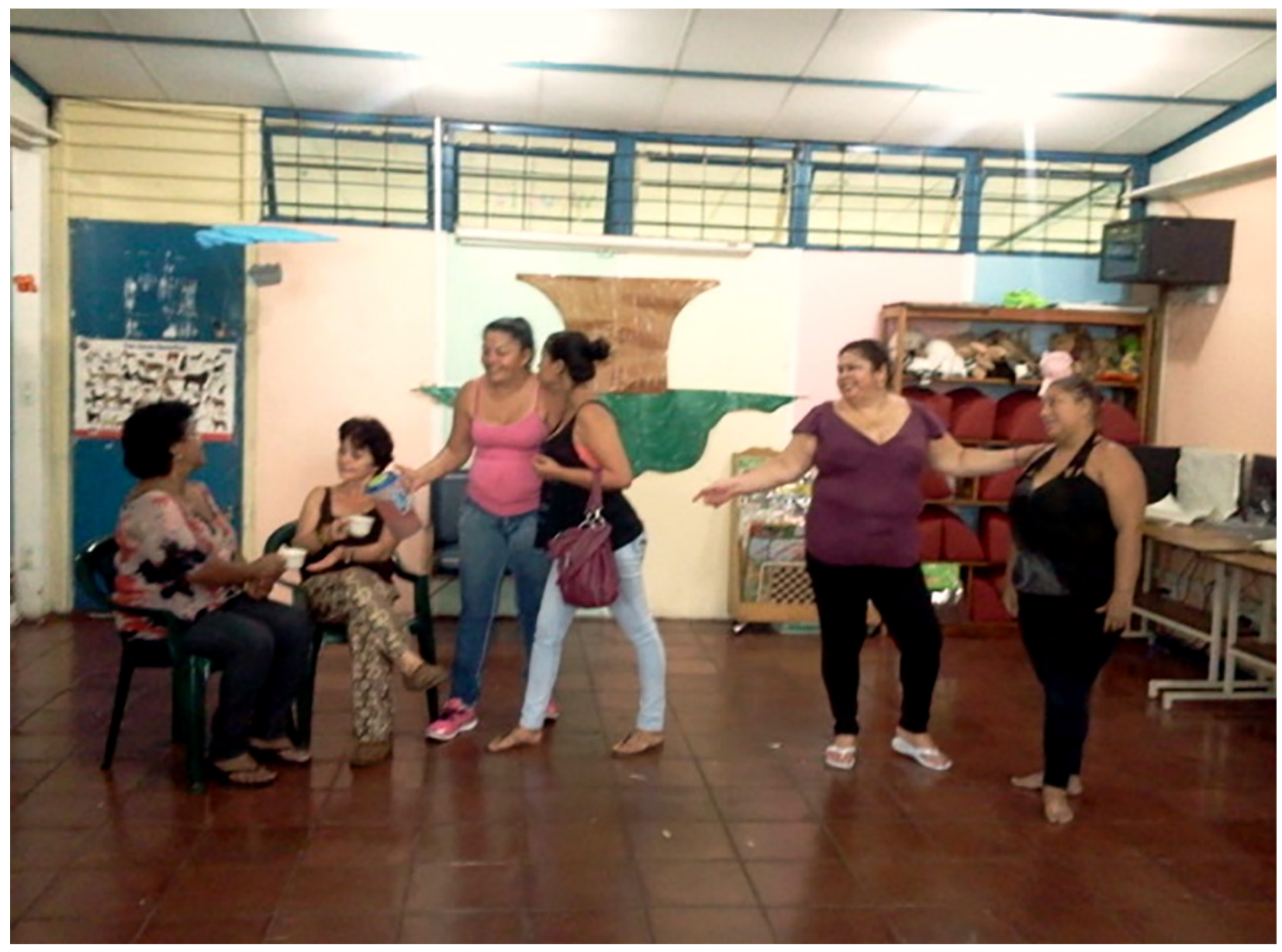

Figura 4: Situación ideal.

Nota: Cada participante ha autorizado el uso de su imagen.

\section{Estrategias de mediación pedagógica}

Entre las formas de mediación utilizadas en el taller, además de las dinámicas de teatro propias del teatro del oprimido, está la realización de lecturas en clase, la narración de cuentos, la realización de calentamientos físicos y vocales, la creación en conjunto de unidades didácticas elaboradas gracias a dos ejercicios que se mantienen durante todos los encuentros: el "Dándole vuelta" y la "Nube de devenires". Transcribimos y compartimos por correo electrónico cada uno de los diez encuentros grabados. 
doi: http://dx.doi.org/10.15359/ree.21-2.3

URL: http://www.una.ac.cr/educare

CORREO: educare@una.cr

\section{El ejercicio “Dándole vuelta”}

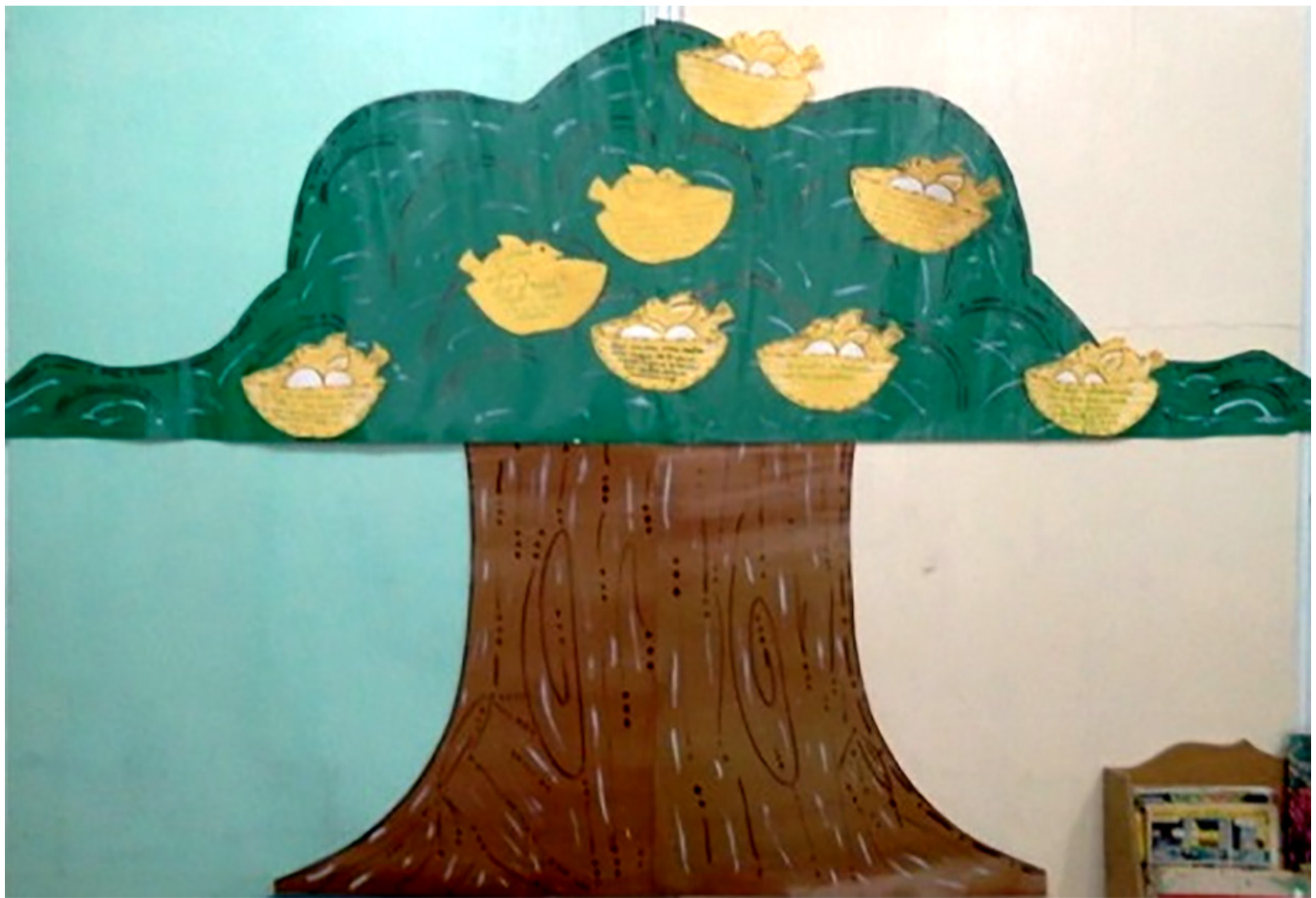

Figura 5: El árbol “Dándole vuelta”.

El ejercicio “Dándole vuelta” (Figura 5) consiste en escribir en papeles los sentires sobre lo vivido en la clase. Esto permite estar en contacto con nuestro proceso de transformación personal durante el taller, para luego compartirlo con las compañeras del grupo. Para desarrollar este ejercicio construimos un árbol de cartón, al cual se le colgaron papeles con forma de animales, hojas y frutas donde se habían escrito los diferentes devenires. Anexamos tres ejemplos del ejercicio "dándole vuelta".

Lidiette: "me gusta mucho el avance que hemos logrado y siento que todo está como tiene que estar". Ninú: "cómo actuamos y me sentí muy bien con todas mis compañeras". Julia: "me gustó mucho porque ya iniciamos lo que va a ser la presentación y hoy tuvimos mucha comunicación, compartimos mucho". 


\section{El ejercicio “Nube de devenires" del taller}

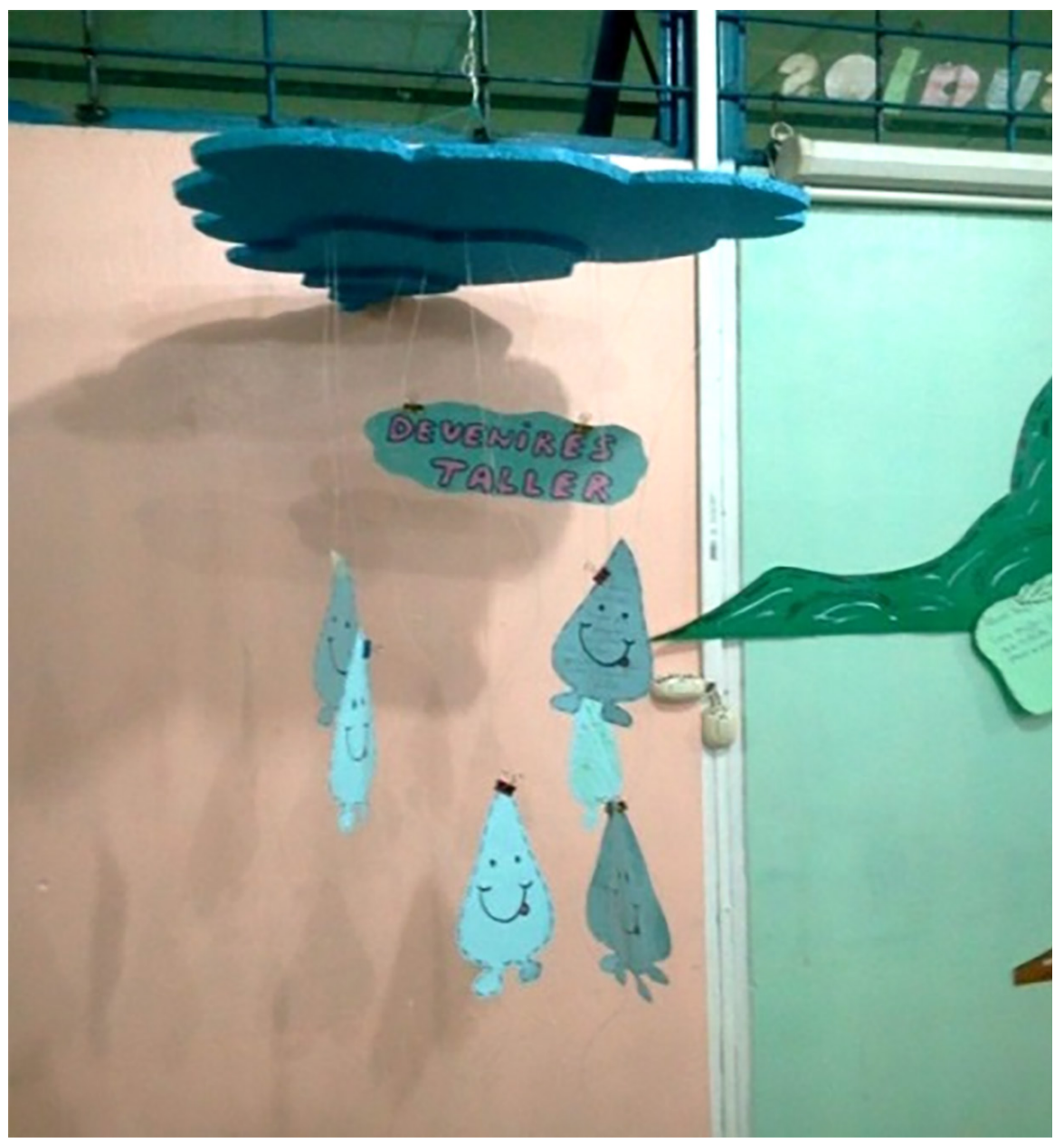

Figura 6: La "Nube de devenires" del taller.

El ejercicio (Figura 6) consiste en realizar una lluvia de ideas y escribir en hojas lo que cada participante considera importante para desarrollar en el próximo encuentro, tanto a nivel de trabajo teatral, como grupal. Para llevar a cabo este ejercicio construimos una nube de estereofón colgante y a los papeles para colgar se les dio forma de gotas de agua, truenos, pájaros, abejas y mariposas. Como ejemplo del ejercicio, las participantes escribieron, Alessandra: "ejercicios de narración y expresión oral". Julia: "quisiera seguir aprendiendo más para ser mejor cada día. Gracias por la enseñanza". Vivian: "un poco más de movimientos relajantes para bajar el estrés. Auto masajes". 
doi: http://dx.doi.org/10.15359/ree.21-2.3

URL: http://www.una.ac.cr/educare

CORREO: educare@una.cr

\section{Reflexión sobre aprendizajes, hallazgos y transformaciones}

Analizamos a continuación los aprendizajes, hallazgos y transformaciones de las coinvestigadoras según las categorías analizadas en la base de esta IAP: la diversidad, la lectura del mundo y el ambiente pedagógico.

Lo que concierne a la primera categoría, el aprendizaje consiste en conocerse desde el valor de la diversidad, tomando conciencia de que los seres humanos somos parte de una biodiversidad humana donde todas las personas tenemos derecho a las mismas oportunidades. En este sentido, cualquier acto de señalación o estigmatización que lleva a etiquetarse a sí misma o a otra persona es percibido como violencia. En este contexto reconocemos un importante poder de la palabra y su efecto ${ }^{7}$ sobre los seres humanos, con lo cual consideramos necesario promover urgentemente una cultura de tolerancia que sea partidaria de utilizar un lenguaje no discriminatorio e inclusivo. Comprendemos consecutivamente que en la base de la no violencia está la aceptación de la otredad, de la diversidad, sea la que sea, incluyendo la propia.

Seguidamente, tomamos conciencia de la existencia del poder y de grupos sociales opresores y oprimidos, y de la importancia de las personas aliadas que les ayudan a surgir. En relación con esto, comprendemos la condición de desventaja del género femenino frente al masculino, analizamos esta condición desde una mirada amplia, como la de la propuesta Queer, donde el género también es una construcción social que sirve para mantener el poder de las clases hegemónicas. El análisis de la desventaja del género femenino frente al masculino nos ha llevado a comprender que, en algún momento de su vida, toda mujer ha sido violada. En este sentido, la violencia puede haber sido vivida en casa o afuera, desde el comentario sobre lo que podemos vestir a un piropo de mal gusto en la calle. Valoramos también el rol de la mujer en la cultura machista como un "ser-paraotros" (Lagarde, 2012, p. 46, citando a Basaglia). Asimismo, tomamos conciencia de que la violencia nace de la frustración, que está a la orden del día, y que se vive como un hecho normal, aunque no lo sea. Consecutivamente, visualizamos la violencia intrafamiliar como una chispa explosiva capaz de expandirse y llegar a un nivel comunitario, a través de su reproducción por parte de la niñez en sus escuelas o de las personas adultas en sus comunidades.

Finalmente, percibimos urgente la promoción de una cultura basada en la solidaridad intergenérica, que radica en la defensa de la libertad y del poderío personal y colectivo para ambos géneros, así como la posibilidad de establecer pactos justos y paritarios entre mujeres y hombres (Lagarde, 2012). En este sentido, aprendemos a ver nuestro entorno con otros ojos y a tener el deseo de rescatar el sentido de colectividad por el cual todos y todas somos comunidad. Ello lleva a apreciar que, si se interactúa con todas las otras personas, podemos aprehender de todas.

${ }^{7}$ En La gramática de la fantasía. Introducción al arte de inventar historias, Rodari (1999) hace una metáfora entre el efecto transformador que puede producir una palabra lanzada al cerebro de un niño y una piedra en el estanque que produce ondas en superficie y profundidad provocando un cambio en todo su entorno. 
En cuanto a lo que concierne a los hallazgos, percibimos la pedagogía como un objeto mágico, que valora la diversidad y transforma los pensamientos, los estilos de vida, los valores de una sociedad y, por ende, la capacidad de los seres humanos de leerse a sí mismos y al mundo. Consecuentemente, visualizamos el objeto mágico como una llave que abre las personas a nuevos conocimientos, a cuartos inexplorados, recónditos y prohibidos. La forma de la llave cambia según las necesidades de quien la utilice, las circunstancias dadas, el momento histórico y los conocimientos construidos.

Adicionalmente, concebimos la pedagogía como un organismo vivo sujeto a continua transformación en pro del bien de la comunidad y para la construcción de una mejor humanidad. Asimismo, reconocemos la importancia de dar a la pedagogía misma nuevos significados, que comprenda una praxis de unión entre procesos vitales y conocimiento. Al respecto, Giroux (1992) afirma que "equivale a comprender la pedagogía como una configuración de prácticas textuales, verbales y visuales que ... [incluya] los procesos ... [con] los cuales la gente se entiende a sí misma y comprende los modos en que [enfrenta] a los demás y a su entorno" (p. 16).

Finalmente, reconocemos el valor de la mediación pedagógica, la cual promueve acercar los métodos, las culturas, las personas, las instituciones, las empresas, los ministerios, las universidades y las comunidades. En sintonía con esto, para la construcción de la mediación pedagógica en el aspecto curricular, consideramos fundamental la interdisciplinariedad de metodologías creativas e integrales, que promuevan la actividad de la escucha, la vitalidad de la convivencia, la libertad y emancipación de la educación. Asimismo, consideramos necesario cambiar el paradigma por el cual las expresiones culturales se dan desde lo institucional de la cultura. Para esto se propone reforzar la idea que es desde lo local donde se debe construir, desde programas intermultidisciplinarios para dar la oportunidad a nuevas personas de construir y decostruir, crear nuevas propuestas que surjan de sus vivencias.

En cuanto a la transformación, utilizar lenguajes inclusivos conduce al valor de "transformarse y transformar", concepto que visualizamos como anillos que generan una cadena de respeto que se trasmite. Sin duda uno de estos anillos está compuesto por una nueva visualización de nosotras, recuperada gracias al ejercicio del dándole vuelta que realizábamos al finalizar nuestros encuentros teatrales:

Nos hemos transformado, nuestras vidas han cambiado, en la forma de no discriminar, de no ofender, de entender que no existe la normalidad, en ver la vida diferente, en reconocer nuestros potenciales, asumir nuestras diversidades y nuestros talentos. Nos convertimos en una familia, nos cuidamos una a la otra, el problema de una es el problema de todas, nos sentimos muy unidas. Crecemos personalmente la una con la otra, sentir que somos todas diferentes nos enriquece. Estar juntas es como un complemento. Gracias al teatro podemos sentirnos "otras" cada día o incluso ir más allá de nuestra condición de género como humanas: hoy podemos ser mujeres, mañana golondrinas, un árbol o una nube. 
doi: http://dx.doi.org/10.15359/ree.21-2.3

URL: http://www.una.ac.cr/educare

CORREO: educare@una.cr

Esta nueva percepción de nosotras mismas como sujetas en continua metamorfosis nos convierte de "ser para los otros individuos", en sujetas para sí mismas y agentes de cambio de la comunidad.

De esta manera, el reconocer las autenticidades de cada una, y practicar la continua deconstrucción y reconstrucción personal, se consideran actividades necesarias para realizar una transformación personal que lleva a potenciar la capacidad de leerse a sí mismas y al mundo.

Importante señalar que el análisis del imaginario social realizado en el taller, gracias a los ejercicios teatrales, nos lleva a percibirnos como "malas madres", queriéndonos salir de cualquier rol impuesto por los imaginarios sociales, religiosos, políticos, o literarios. En relación con esta nueva percepción de nosotras mismas, decidimos tener una mascota: la planta llamada popularmente "mala madre" porque tira a sus hijos fuera de su tallo.

\section{Consideraciones finales y devenires de la investigación}

Invitamos al público lector a acompañarnos en las consideraciones finales y devenires de nuestra IAP mediante la escucha de la pieza "Divenire" (traducción propia del italiano: devenires), del álbum ${ }^{8}$ con el mismo nombre del compositor Einaudi (2006). El actual momento histórico refleja que la humanidad se encuentra en una crisis general, en un punto crucial (Capra, 1992), que es el reflejo de la decadencia de nuestra civilización, fundamentada aún en una visión anticuada del mundo: cartesiana y mecanicista.

Teniendo en cuenta que la realidad ya no puede comprenderse desde este punto de vista, consideramos urgente crear nuevos paradigmas que permitan la transformación de nuestros pensamientos, percepciones y valores. Para esto es fundamental revisitar la estructura lógico lineal que está en la base de la construcción del actual pensamiento humano, y promover nuevas estructuras de este mismo que reflejen formas orgánicas y sistémicas de pensar (Capra, 2008). En esta perspectiva, la vida, la educación, la pedagogía, la ciencia, la diversidad y el mundo se perciben desde un enfoque relacionado con la complejidad. Pensamos que, mediante este nuevo paradigma, donde cada particularidad es un torbellino de entropía en contacto con la multiplicidad de un todo, es posible promover relaciones ecológicas entre los mismos seres humanos y con el medio ambiente, para la construcción de un mundo más solidario y cooperativo.

En igual sentido, revalidamos que en la base del posible cambio de paradigmas está la capacidad de los seres humanos de leerse a sí mismos y al mundo. Para esto creemos que es sumamente necesario un cambio en el currículo del sistema educativo en nuestro país,

\footnotetext{
${ }^{8}$ Se puede escuchar la pieza "Devenire" en https://www.youtube.com/watch?v=X1DRDcGISsE
}

\begin{tabular}{l|l}
\hline 24 & Simona Trovato-Apollaro
\end{tabular}


que debe ser partidario de una formación educativa continua que contemple metodologías multidisciplinarias y creativas, que comprenda además procesos de acción-reflexión y praxis en torno a la construcción del conocimiento.

En cuanto a los devenires de esta IAP, estuvieron presentes desde el primer encuentro, cuando al final de cada taller practicábamos los ejercicios “Dándole vuelta"y"Nube de devenires". Estos ejercicios que representan una forma de construir conocimiento desde una perspectiva dialéctica nos permitieron visualizar el trabajo realizado a diario $y$, al mismo tiempo, construir una mirada común que se proyectaba cada vez más lejos.

En nuestros devenires está la visión de que los centros culturales o educativos, y en particular las bibliotecas, puedan ser puntos de encuentro de la comunidad y para esta. Puntos de encuentro donde se construye y deconstruye conocimiento desde las necesidades de sus mismos "espectactores" $y$ "espectactrices", en colaboración con distintas instituciones educativas, culturales, públicas o privadas del país.

Asimismo, como grupo Mujeres de Teatro nos sentimos preparadas para involucrar a más personas de la comunidad, tanto mujeres como hombres, para en un segundo momento, llevar la experiencia a todas las bibliotecas escolares de Alajuelita o a otras municipalidades.

Nuestro deseo es reproducir el taller en otras poblaciones para visualizarlo a largo plazo de una manera diferente, como grupo y como comunidad. De la misma forma, el propósito de las futuras presentaciones será enfrentar la violencia que se vive en el barrio de Alajuelita, recordar las pérdidas, sin hundirse solo en el dolor, más bien buscando otras formas de enfrentarlas y de vivir.

Actualmente, el grupo Mujeres de Teatro se consolida como colectivo teatral y "como seres de la praxis, es decir, de la acción y la reflexión sobre el mundo" (Freire, 2004, p. 75), para ayudarse a sí mismas, a más mujeres de Alajuelita y a otras comunidades.

Para finalizar, al ser incuestionable la vinculación entre literatura, cultura, pedagogía, historia y política, se presentan nuevas categorías a profundizar, que surgen de esta IAP. Estas son las señaladas por Calvino (2012) en su libro Seis propuestas para próximo milenio: la levedad, la rapidez, la exactitud, la visibilidad y la multiplicidad. Las nuevas categorías traen nuevas preguntas: ¿cómo podemos sacudirnos de esquemas mentales rígidos, verticalismos y autoritarismos innecesarios para vernos como una nueva multiplicidad de átomos que pueden funcionar y coexistir?, ¿en cuál tiempo-ritmo queremos transformarnos?, ¿qué queremos transformar?, ¿cómo nos imaginamos como especie humana?

Investigar estas nuevas categorías y preguntas permitirá profundizar el tema central de esta IAP; consolidar vínculos con pedagogías ligadas a la diversidad, a la imaginación, a la complejidad; esto nos consentirá salir de un yo individual, entrar en otros yoes y seguir desarrollando cambios en nuestra lectura del mundo. 
doi: http://dx.doi.org/10.15359/ree.21-2.3

URL: http://www.una.ac.cr/educare

CORREO: educare@una.cr

\section{Referencias}

Boal, A. (1980). Teatro del oprimido 1. Teoría y práctica. México: Nueva Imagen.

Boal, A. (2004). El arco iris del deseo. Del teatro experimental a la terapia. Barcelona: Alba editorial.

Calvino, I. (2012). Seis propuestas para el próximo milenio. Madrid: Siruela.

Capra, F. (1992). El punto crucial. Ciencia, sociedad y cultura naciente. Buenos Aries: Troquel.

Capra, F. (2008). La ciencia de Leonardo. La naturaleza profunda de la mente del gran genio del renacimiento. Barcelona: Anagrama.

Castoriadis, C. (1993). La institución imaginaria de la sociedad. En E. Colombo (Coord.), El imaginario social. Montevideo: Altamira y Nordan Comunidad.

De Gregori, F. (1985). La storia. En Scacchi e Tarocchi [CD]. Milano: RCA italiana. Recuperado de https://it.wikipedia.org/wiki/Scacchi e tarocchi

Dolz, A. y Rogero, J. (2012). Amor y cuidado, claves de la educación para un mundo nuevo. Revista Interuniversitaria de Formación del Profesorado, 74(26,2), 97-113. Recuperado de http://www.aufop.com/aufop/uploaded files/revistas/13515482627.pdf\#page=97

Einaudi, L. (2001). I giorni. En I giorni [CD]. Briosco: Sony Classical. Octubre 2001. Recuperado de https://en.wikipedia.org/wiki/l Giorni

Einaudi, L. (2004). Nuvole bianche. En Una mattina [CD]. Milano: Universal/Decca. Recuperado de https://it.wikipedia.org/wiki/Una mattina

Einaudi, L. (2006). Divenire. En Divenire [CD]. Recuperado de https://es.wikipedia.org/wiki/ Ludovico Einaudi

Fonseca, C. y Quintero, M. L. (2009). La teoría Queer: La de-construcción de las sexualidades periféricas. Sociológica, 24(69), 43-60. Recuperado de http://www.revistasociologica.com.mx/pdf/6903.pdf

Freire, P. (1972). La pedagogía del oprimido. Buenos Aires: Siglo XXI Editores.

Freire, P. (1982). La educación como práctica de la libertad. México DF: Siglo XXI Editores.

Freire, P. (2004). La importancia de leer y el proceso de liberación (16ª ed.). México DF: Siglo XXI Editores.

Freire, P. (2002). Pedagogía de la esperanza. Un reencuentro con la pedagogía del oprimido (5a. ed.). Buenos Aires: Siglo XXI Editores. 
Giroux, H. A. (1992). Cruzando límites. Trabajadores culturales y políticas educativas. Barcelona: Paidós. Lagarde, M. (2012). El feminismo en mi vida. Hitos, claves y topías. México: Instituto de las Mujeres del Distrito Federal. Recuperado de http://www.cotidianomujer.org.uy/sitio/pdf/ ElFeminismoenmiVida.pdf

Link, B. G. y Phelan, J. C. (2001). Conceptualizing stigma. Annual Review of Sociology, 27, 363-85. doi: https://doi.org/10.1146/annurev.soc.27.1.363

Matos, J. (2011). El imaginario social sobre el teatro, tradición sociológica e interdisciplinariedad. Contribuciones a las Ciencias Sociales, 16. Recuperado de http://www.eumed.net/rev/ cccss/16/jmg.html

Matunara, H. (2002). Transformación en la convivencia. Santiago, Chile: Dolmen Ediciones.

Mcintosh P. (1989). White privilege: Unpacking the invisible knapsack. Peace and Freedom Magazine, 10-12. Recuperado de http://nationalseedproject.org/white-privilegeunpacking-the-invisible-knapsack

Murillo, A. (14 de setiembre de 2014). Costa Rica: El país sin ejército que aloja medio millón de armas. La Nación. Recuperado de http://www.nacion.com/nacional/salud-publica/CostaRica-ejercito-millon-armas 0 1439056133.html

Obando, A. (2011). Educación género sensitiva: Paradigma de una cultura de paz. En S. López, A. M. Rodino y A. E. Obando (Coord.), Desarrollo profesional para construir una cultura de paz. San José, Costa Rica: Unesco y Universidad de la Paz.

Olimpio, G. (12 de enero de 2015). Innocenti e insospettabili per sfuggire ai controlli. Ecco come le usano i militanti. Diritti Globali. Recuperado de http://www.dirittiglobali.it/2015/01/ innocenti-insospettabili-per-sfuggire-controlli-come-usano-i-militanti /

Regina, C. (25 de mayo, 2013). Como se siente una mujer [Mensaje en un blog]. Recuperado de http://elblogdematina.blogspot.com/2013/05/como-se-siente-una-mujer.html

Redacción. (27 de octubre de 2014). Honduras registró 4,217 crímenes contra mujeres entre 2002 y 2014. El Heraldo. Recuperado de http://www.elheraldo.hn/inicio/762208-209/ honduras-registr\%C3\%B3-4217-cr\%C3\%ADmenes-contra-mujeres-entre-2002-y-2014

Rodari,G.(1999).Lagramáticadelafantasía.Introducciónalartedeinventarhistorias. Barcelona:Ediciones del Bronce. Recuperado de http://cungraficos.weebly.com/uploads/5/0/0/7/5007473/ rodarigianni-gramaticadelafantasiaintroduccionalartedeinventarhistorias.pdf 
doi: http://dx.doi.org/10.15359/ree.21-2.3

URL: http://www.una.ac.cr/educare

CORREO: educare@una.cr

Salas, L. (23 de septiembre del 2012). Víctimas de violencia vulnerabilizan su condición por ausencia de guía en el proceso legal. Crhoy.com. Recuperado de http://www.crhoy.com/ victimas-de-violencia-vulnerabilizan-su-condicion-por-ausencia-de-guia-en-el-procesolegal/?fb $\mathrm{ref}=\mathrm{AL} 2 \mathrm{FB}$

Taylor, C. (2006). Imaginarios sociales modernos. Barcelona: Paidós.

Trovato, S., Hernández, G. y Acuña, M. (18 diciembre 2014). Proyecto Ser natural Costa Rica [Video youtube]. Recuperado de https://www.youtube.com/watch?v=oVs45MfrhAl\&t=60s 